\title{
Effect of grassland cutting frequency on soil carbon storage - a case study on public lawns in three Swedish cities
}

\author{
C. Poeplau ${ }^{1,2}$, H. Marstorp ${ }^{3}$, K. Thored ${ }^{1}$, and T. Kätterer ${ }^{1}$ \\ ${ }^{1}$ Swedish University of Agricultural Sciences (SLU), Department of Ecology, Box 7044, \\ 75007 Uppsala, Sweden \\ ${ }^{2}$ Thuenen Institute of Climate-Smart Agriculture, Bundesallee 50, 38116 Braunschweig, Germany \\ ${ }^{3}$ Swedish University of Agricultural Sciences (SLU), Department of Soil and Environment, Box 7014, \\ 75007 Uppsala, Sweden
}

Correspondence to: C. Poeplau (christopher.poeplau@ thuenen.de)

Received: 11 November 2015 - Published in SOIL Discuss.: 18 January 2016

Revised: 4 April 2016 - Accepted: 13 April 2016 - Published: 25 April 2016

\begin{abstract}
Soils contain the largest terrestrial carbon pool and thus play a crucial role in the global carbon cycle. Grassland soils have particularly high soil organic carbon (SOC) stocks. In Europe (EU 25), grasslands cover $22 \%$ of the land area. It is therefore important to understand the effects of grassland management and management intensity on SOC storage. City lawns constitute a unique study system in this context, since they provide a high functional diversity and thus a wide range of different management intensities per unit area. In this study we investigated frequently mown (on average eight times per season) utility lawns and rarely mown (once per season) meadow-like lawns at three multi-family housing areas in each of three Swedish cities: Uppsala, Malmö, and Gothenburg. The two different lawn types were compared regarding their aboveground net primary production (NPP) and SOC storage. In addition, root biomass was determined in Uppsala. We found significantly higher aboveground NPP and SOC concentrations and significantly lower soil $\mathrm{C}: \mathrm{N}$ ratio for the utility lawns compared with the meadow-like lawns. On average, aboveground NPP was $24 \%$ or $0.7 \mathrm{MgC} \mathrm{ha}^{-1} \mathrm{yr}^{-1}$ higher and SOC was $12 \%$ or $7.8 \mathrm{Mg} \mathrm{ha}^{-1}$ higher. Differences in SOC were well explained by differences in aboveground NPP $\left(R^{2}=0.39\right)$, which indicates that the increase in productivity due to more optimum $\mathrm{CO}_{2}$-assimilating leaf area, leading to higher carbon input to the soil, was the major driver for soil carbon sequestration. Differences in soil $\mathrm{C}: \mathrm{N}$ ratio indicated a more closed $\mathrm{N}$ cycle in utility lawns, which might have additionally affected SOC dynamics. We did not find any difference in root biomass between the two management regimes, and concluded that cutting frequency most likely only exerts an effect on SOC when cuttings are left on the surface.
\end{abstract}

Soils contain the largest terrestrial carbon pool (Chapin et al., 2009). The balance of soil organic carbon (SOC) inputs and outputs is therefore critical for the global carbon balance and thus for the concentration of greenhouse gases in the atmosphere. Globally, 3650 Mha or $68 \%$ of the total agricultural area is used as pasture or meadows (Leifeld et al., 2015). In Europe (EU 25), grassland covers $22 \%$ of the land area (Soussana et al., 2007). Grassland soils store among the highest amounts of SOC, which is primarily related to the high belowground carbon input by roots and their exudates (Bolinder et al., 2012). Soils rich in SOC are potential hotspots for $\mathrm{CO}_{2}$ emissions when a management or landuse-change-induced imbalance in carbon input and output occurs. It is therefore important to understand the effect of management practices on grassland SOC storage. It has been demonstrated that the type, frequency, and intensity of net primary production (NPP) appropriation (harvest) can play a 
crucial role for the carbon balance and SOC stocks of grassland ecosystems (Soussana et al., 2007).

One direct management intensity effect on SOC which is mediated by grazing, cutting, or fertilisation regime is obviously the change in carbon input via the degree of biomass extraction and altered photosynthetic activity (Wohlfahrt et al., 2008). Furthermore, above- and belowground allocation patterns may change with cutting frequency (Seiger and Merchant, 1997). Recently, Leifeld et al. (2015) reported faster root turnover in moderately and intensively managed alpine grasslands than at less intensively grazed sites. They concluded that management is a key driver for SOC dynamics and should be included in future predictions of SOC stocks. Nutrient status, species composition, and diversity are highly management-dependent and interfere with the carbon cycle in several ways, including effects on the decomposer community and its substrate use efficiency (Ammann et al., 2007; Kowalchuk et al., 2002).

Management effects on SOC are presumably smaller than land use change effects such as conversion from permanent pasture to arable land (Poeplau and Don, 2013) and might not be visible in the short term. To assess those changes, it is therefore important to find suitable study systems with long-lasting strong contrasts in management intensity over a limited spatial scale and with limited soil variability. For agroecosystems, this situation is usually created in long-term experiments which are designed to study such questions. In a global compilation of all existing agricultural long-term field experiments, only 49 out of $>600$ experiments are listed as including permanent grassland (pasture or meadow) (Debreczeni and Körschens, 2003). Thus, the current quantitative and mechanistic understanding of grassland management effects on SOC stocks is certainly limited, since existing studies are often strongly confounded by external factors such as elevation gradients (Leifeld et al., 2015; Zeeman et al., 2010). As an alternative to long-term plot experiments, urban areas can be appropriate study systems. Lawns, public green areas, and parks are omnipresent in urban areas and are usually managed in a similar way for a long time, so that, depending on the prior land-use-type equilibrium, SOC stocks might be approximated (Raciti et al., 2011). Over a comparatively small spatial scale, a wide range of different management intensities can be present.

Urban areas are more rapidly expanding than any other land-use type (Edmondson et al., 2014). Turfgrass lawns cover the majority of all green open spaces in urban landscapes (70-75\%) according to Ignatieva et al. (2015). It has been estimated that turfgrass lawns cover approximately 16 Mha of the total US land area, which in the 1990s was 3-fold the area of irrigated maize (Milesi et al., 2005; Qian et al., 2010). Although robust global estimates of the coverage of turfgrass lawns are scarce, these few existing figures indicate the potential importance of lawn management for the global carbon cycle. Furthermore, several studies have reported higher SOC stocks under urban land use as compared to surrounding soils, which might be a feature of high management intensity in urban ecosystems (Edmondson et al., 2012; Pouyat et al., 2009). There is thus a need to quantify the carbon footprint of differently managed lawns, for which SOC is of major importance. In the transdisciplinary Swedish LAWN project (http://www.slu.se/lawn), lawns were studied from social, ecological, and aesthetic perspectives (Ignatieva et al., 2015).

In this study, as part of the LAWN project, we analysed two types of lawn under different management intensity (cutting frequency) associated with multi-family housing areas which were intensively monitored at three sites in each of three Swedish cities. The objectives of the study were (i) to examine how cutting frequency affected NPP, SOC, and soil carbon to nitrogen ratio $(\mathrm{C}: \mathrm{N})$ and (ii) to reveal involved mechanisms causing differences in SOC between the two management regimes.

\section{Materials and methods}

\subsection{Study sites}

Public lawns in multi-family housing areas were investigated in three different cities - Gothenburg, Malmö, and Uppsala - and at three different sites in each city (Table 1). The nine selected multi-family housing areas were established at approximately the same time during the early 1950s. At each site, triplicate plots of two different lawn types were studied: utility lawn and meadow-like lawn, with each plot comprising one complete lawn. The utility lawn was kept short during the year and was mown on average every 18 days within the mowing period (eight times), which approximately corresponds with the growing period (May to mid-October in Uppsala, and April to late October in Gothenburg and Malmö). The meadow-like lawns were only cut once, or twice in the single case of one lawn in Uppsala (Tuna Backar). Grass cuttings were left on the surface on both lawn types. None of the lawns received any fertiliser. Grass species composition did not differ greatly between the cities, with about 5-10 different grass species abundant in utility lawns and meadowlike lawns. Utility lawns consisted of sparser, low-growing species such as Poa annua, Agrostis capillaris, Lolium spp., and Festuca rubra, while the most abundant grass species in meadow-like lawns were Phleum pratense, Alopecurus pratensis, and Arrhenatherum spp. (J. Wissman, personal communication, 2015). The size of the individual lawns was highly unequal with a range of $0.05-2.5$ ha due to the heterogeneity of urban landscapes. To obtain representative average values for the whole individual lawn, we conducted all samplings described below adjusted to the size of the lawn, instead of using a "fixed grid". 
Table 1. Site characterisation with year of establishment; mean annual temperature [MAT, $\left.{ }^{\circ} \mathrm{C}\right]$ and mean annual precipitation [MAP, mm] (1961-1990); and clay, silt, and sand content [\%] as well as soil pH for utility lawns (U) and meadow-like lawns (M) for all three Swedish cities studied.

\begin{tabular}{|c|c|c|c|c|c|c|c|c|c|c|c|c|c|}
\hline \multirow[t]{2}{*}{ City } & \multirow[t]{2}{*}{ Site } & \multirow[t]{2}{*}{ Age } & \multirow[t]{2}{*}{ MAT } & \multirow[t]{2}{*}{ MAP } & \multirow[t]{2}{*}{$\mathrm{C}: \mathrm{N}$} & \multicolumn{2}{|c|}{ Clay } & \multicolumn{2}{|c|}{ Silt } & \multicolumn{2}{|c|}{ Sand } & \multicolumn{2}{|c|}{$\mathrm{pH}^{*}$} \\
\hline & & & & & & $\mathrm{U}$ & M & $\mathrm{U}$ & M & $\mathrm{U}$ & M & $U^{1}$ & M \\
\hline \multirow[t]{3}{*}{ Uppsala } & Eriksberg & 1949 & 5.5 & 527 & 12.8 & 36 & 46 & 43 & 44 & 21 & 10 & $\sim 6$ & $\sim 6$ \\
\hline & Sala Backe & 1950 & & & 12.5 & 45 & 45 & 47 & 51 & 8 & 4 & $\sim 6$ & $\sim 6$ \\
\hline & Tuna Backar & 1951 & & & 13.1 & 33 & 23 & 47 & 45 & 20 & 32 & $\sim 6$ & $\sim 6$ \\
\hline \multirow[t]{3}{*}{ Malmö } & Kirseberg & 1950 & 8.4 & 540 & 12.7 & 12 & 10 & 49 & 46 & 39 & 45 & 7.2 & 7.2 \\
\hline & Sibbarp & 1953 & & & 13.8 & 15 & 15 & 48 & 47 & 38 & 38 & 7.4 & 7.8 \\
\hline & Augustenborg & 1952 & & & 13.9 & 13 & 10 & 49 & 45 & 38 & 45 & 7.4 & 7.7 \\
\hline \multirow[t]{3}{*}{ Gothenburg } & Guldheden & $1950^{\mathrm{a}}$ & 7.4 & 714 & 14.1 & 16 & 14 & 45 & 44 & 39 & 42 & 5.5 & 5.4 \\
\hline & Kyrkbyn & 1955 & & & 12.0 & 16 & 22 & 62 & 55 & 21 & 23 & 5.8 & 5.7 \\
\hline & Björkekärr & $1950^{\mathrm{a}}$ & & & 12.8 & 14 & 16 & 49 & 58 & 37 & 27 & 5.5 & 5.7 \\
\hline
\end{tabular}

$a$ year only approximate. ${ }^{*} \mathrm{pH}$ values for the Uppsala sites were not measured, and the values shown are estimates based on typical values for soils in Uppsala (e.g. Kätterer et al., 2011).

\subsection{Estimation of aboveground net primary production and root biomass}

Aboveground NPP in the utility lawns was estimated by repeated sampling of aboveground biomass after the first mowing in spring by the local authority. Sampling was conducted on average $12 \pm 6$ days after each mowing event. For the meadow-like lawns, biomass was collected on several occasions even before the mowing to determine total growth at that specific time. After the first cut, meadow-like lawns were treated as utility lawns. The plots were sampled at four locations using a $50 \mathrm{~cm} \times 50 \mathrm{~cm}$ square frame. Sampling locations were selected to be representative of the total lawn area, so therefore sampling under trees or in proximity to other vegetation was avoided. Repeated sampling was not conducted on the identical sampling locations. The harvested biomass was dried at $70^{\circ} \mathrm{C}$, weighed, and multiplied by 4 to obtain the biomass for $1 \mathrm{~m}^{2}$. The mean of the four replicates was divided by the number of days between the last cutting and sampling to obtain daily growth rate. This growth rate was extrapolated to cover all days between previous sampling and next mowing for which no growth rate was determined. On average, this period accounted for $7 \pm 6$ days after each cutting event, and thus data coverage (time for which the actual growth rate was measured) was more than $82 \pm 6 \%$ for the period between 1 January and the last sampling date, which was on average on 5 October \pm 7 days. On the basis of these daily growth rates, we calculated cumulative growth until the last sampling. Since this day varied slightly between plots and sites, we fitted a simple vegetation model based solely on the plant response to air temperature, as developed by Yan and Hunt (1999) to each growth curve in order to determine the regrowth after the last sampling until the end of the vegetation period. The original equation is
$r=R_{\max }\left(\frac{T_{\mathrm{max}}-T}{T_{\mathrm{max}}-T_{\mathrm{opt}}}\right)\left(\frac{T}{T_{\mathrm{opt}}}\right)^{\frac{T_{\mathrm{opt}}}{T_{\mathrm{max}}-T_{\mathrm{opt}}}}$,

where $r$ is the daily rate of plant growth, $T$ is the measured temperature at any day, $T_{\max }$ is the maximum temperature (which was set to $30^{\circ} \mathrm{C}$ in this study), $T_{\text {opt }}$ is the optimal temperature (which was set to $25^{\circ} \mathrm{C}$ in this study), and $R_{\max }$ is the maximal growth rate at $T_{\mathrm{opt}}$. Instead of using $R_{\max }$, which is used in Eq. (1) to scale the temperature response function to actual observed maximal plant growth at optimal temperature, we scaled the model by forcing the cumulated $r$ through the cumulated NPP value on the date of the last sampling, as illustrated in Fig. 1 using the example of the Björkekärr site in Gothenburg. The good fit indicates that (i) the growth dynamics, and thus absolute growth, were well captured by the method used and (ii) the model fits provide an unbiased and standardised extrapolation of aboveground NPP for the entire growing period. Daily mean air temperature values for the closest weather stations of the Swedish Meteorological Service (SMHI) to Malmö and Gothenburg were downloaded from http://www.smhi.se/klimatdata. Daily average air temperature values for Uppsala were obtained from the Ultuna climate station run by the Swedish University of Agricultural Sciences (SLU).

Root biomass was only determined once, and only in Uppsala. In each lawn, four cylindrical soil cores of $7 \mathrm{~cm}$ diameter and $10 \mathrm{~cm}$ depth were taken at $0-10 \mathrm{~cm}$ soil depth. Aboveground plant material was removed and soil cores were thoroughly rinsed and then put in a water bucket to completely separate roots from soil. Roots were dried at $105^{\circ} \mathrm{C}$ weighed and analysed for carbon (C) and nitrogen (N) content. Assuming a carbon content of $45 \%$ for plant biomass, we were able to determine and subtract the adhering soil in the weighed root samples mathematically, as described in Janzen et al. (2002). 


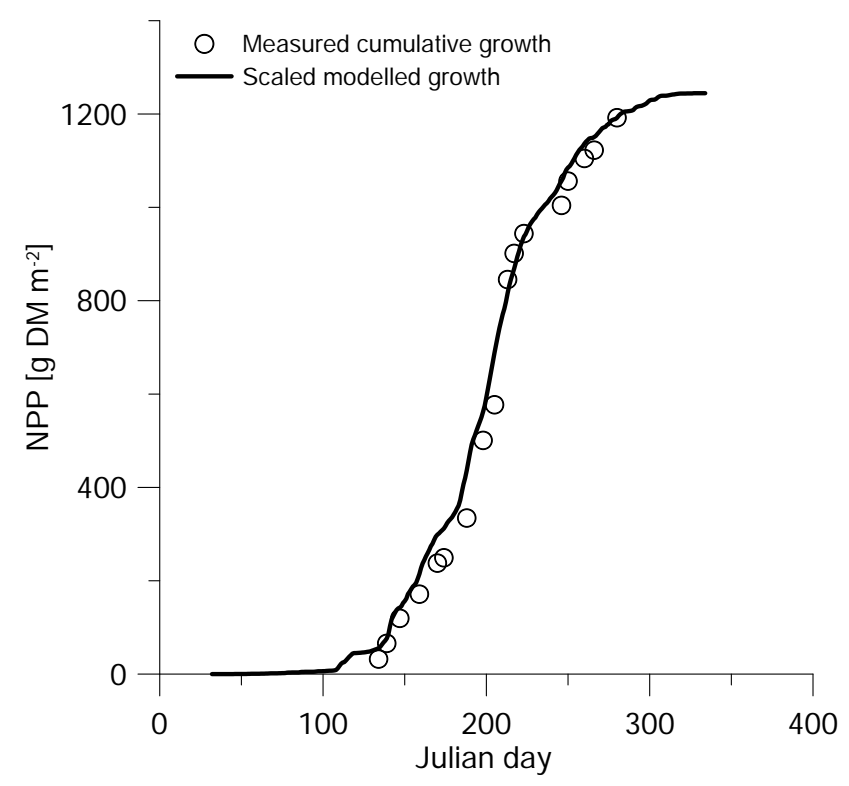

Figure 1. Example of the vegetation model (Eq. 1) fit to a calculated cumulative growth curve for a utility lawn in Björkekärr, Gothenburg.

\subsection{Soil sampling, analysis, and SOC stock calculation}

Soils were sampled in autumn 2014 to a depth of $20 \mathrm{~cm}$ using an auger $(2.2 \mathrm{~cm}$ diameter). In each plot, 10 randomly distributed soil cores were taken and pooled to one composite sample. Soils were dried at $40^{\circ} \mathrm{C}$, sieved to $2 \mathrm{~mm}$, and visible roots were manually removed. Soil $\mathrm{pH}$ was determined in water and samples with a $\mathrm{pH}$ value exceeding 6.7 were analysed for carbonates. Soil texture was determined with the pipette method according to ISO 11277. As a slight modification, wet sieving prior to sedimentation was done to $0.2 \mathrm{~mm}$ compared to $0.063 \mathrm{~mm}$ prescribed in the ISO method. Total soil carbon and nitrogen were determined by dry combustion of $1 \mathrm{~g}$ of soil using a LECO TruMac CN analyser (St. Joseph, MI, USA) and carbonate carbon was determined using the same instrument after pretreatment overnight at $550^{\circ} \mathrm{C}$. Organic soil carbon was calculated as the difference between total carbon and carbonate carbon. Soil bulk density $\left[\mathrm{g} \mathrm{cm}^{-3}\right]$ was determined by taking undisturbed cylindrical soil cores of $7 \mathrm{~cm}$ diameter and $10 \mathrm{~cm}$ height in an approximate soil depth of $5-15 \mathrm{~cm}$, drying them at $105^{\circ} \mathrm{C}$, and weighing them. Four samples were taken in each plot. To account for the fact that SOC stocks under contrasting management regimes should be compared on the basis of equivalent soil masses (Ellert and Bettany, 1995), we conducted a simple mass correction in which we first calculated the soil mass (SM) $\left[\mathrm{Mg} \mathrm{ha}^{-1}\right]$ of each plot using the equation

$\mathrm{SM}=\mathrm{BD} \times D \times 100$,

where $\mathrm{BD}$ is the soil bulk density $\left[\mathrm{g} \mathrm{cm}^{-3}\right]$ and $D$ is the sampling depth $[\mathrm{cm}]$. The lower average soil mass measured at each pair was then used as the reference soil mass (RSM) to which the other treatment of each pair (three pairs per site) were adjusted.

SOC stocks $\left[\mathrm{Mgha}^{-1}\right]$ were then calculated using the equation:

SOCstock $=\mathrm{RSM} \times \frac{C}{100}$

where $C$ is carbon concentration [\%]. At one site in Gothenburg (Kyrkbyn), one pair of lawn types had a large difference in soil texture, with $15 \%$ clay in the utility lawn and $30 \%$ in the meadow-like lawn. The SOC concentration varied by a similar amount (2.46\% compared with $4.58 \%)$, which was an outlying high difference when compared with that of all other pairs. We attributed this to differences in soil texture and excluded this pair from the analysis. Apart from slight differences in soil texture, the basic assumption was that the underlying pedology and initial soil carbon stocks were similar for both lawn types, or at least not systematically biased. Differences in soil texture between lawn types at each site was further not correlated to differences in SOC concentration $\left(R^{2}=0.02\right)$.

\subsection{Statistics}

All statistical analyses were performed with R software version 3.1.2. We used linear mixed effect models to analyse the effect of lawn management on aboveground NPP and SOC concentration and stocks using the $\mathrm{R}$ package nlme (Pinheiro et al., 2009). Management (utility vs. meadow-like lawn) was used as the fixed effect, while city and site were used as nested random effects (site nested in city). We used Tukeytype multiple comparison post hoc analysis (R package multcomp) to test the management effect at each site for significance $(p<0.05)$. Average differences in SOC stocks between the different lawn types at each site (dependant variable) were calculated and related to different explanatory variables (independent variables), such as average clay content, differences in clay content between lawn types (absolute and relative), soil $\mathrm{pH}$, mean annual temperature (MAT), mean annual precipitation (MAP), and differences in aboveground NPP. Generalised linear models with Gaussian error distribution were used for multiple regression analysis. Model performance was evaluated using the Akaike information criterion (AIC). The variable "clay content" had to be transformed to approximate normal distribution. For both model approaches (mixed effect model and generalized linear model) we used residual plots to study whether (i) the regression function was linear, (ii) the error terms had constant variance, (iii) the error terms were independent, (iv) there were outliers, or (v) the error terms were normally distributed. All values in the text and diagrams represent mean \pm standard deviation. 


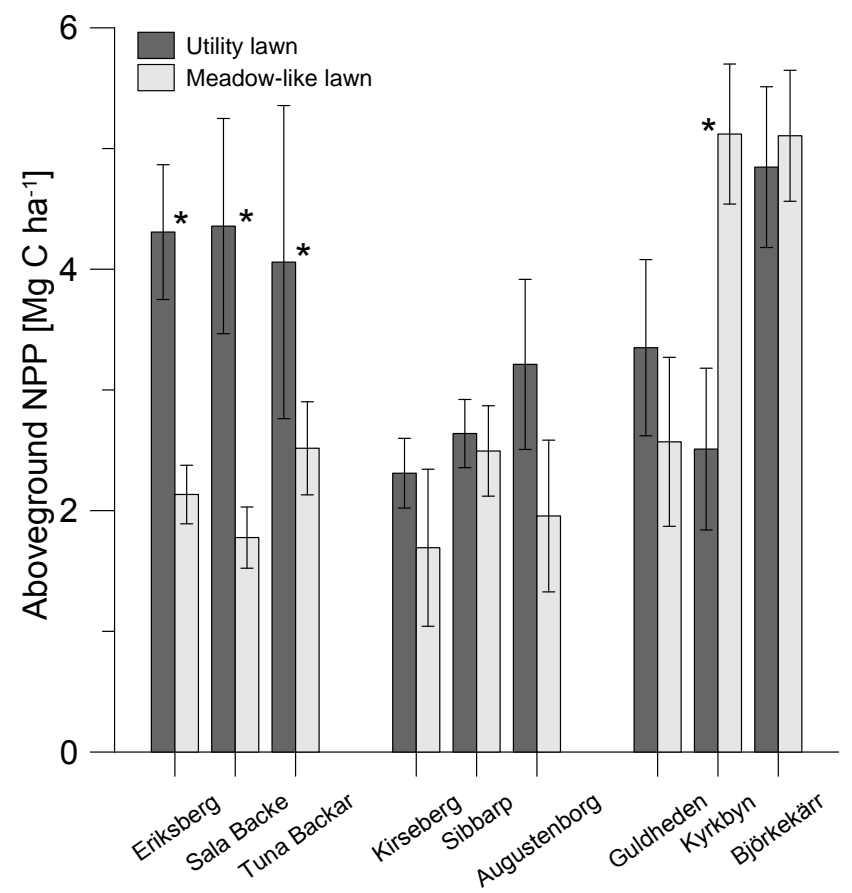

Figure 2. Bar plot showing estimated aboveground net primary production (NPP) of the two different lawn types at each site. Error bars indicate standard deviation and stars indicate significant difference between treatments at the specific site $(p<0.05)$.

\section{Results}

\section{Effect of lawn management on net primary production and soil carbon and nitrogen}

The intensively managed, i.e. frequently mown, utility lawns produced significantly $(p=0.003)$ more aboveground biomass (NPP) than the meadow-like lawns, which were cut only once a year (Fig. 2). At seven out of nine sites, NPP was higher in the utility lawns than in the meadow-like lawns. The difference between the lawn types was most pronounced in Uppsala, where the average NPP of the utility lawns $\left(4.2 \pm 0.9 \mathrm{MgCha}^{-1}\right)$ was twice that of the meadowlike lawns $(2.1 \pm 0.3)$. In contrast, two out of three sites in Gothenburg showed higher NPP on the meadow-like lawns. Across all sites, the NPP of the utility lawns was $24 \%$ higher. Total root biomass, as investigated at the three sites in Uppsala, was not significantly influenced by management intensity and indicated a smaller ratio of belowground to aboveground NPP in meadow-like lawns (Fig. 3).

Concentrations of SOC were also positively affected by greater cutting frequency. Utility lawns had significantly higher $(p=0.01)$ SOC concentration than meadow-like lawns (Fig. 4). Again, the difference between the two lawn types was most pronounced in Uppsala, with an average SOC concentration of $3.9 \pm 0.6 \%$ in the utility lawns and $2.9 \pm 0.9 \%$ in the meadow-like lawns. In both Malmö and

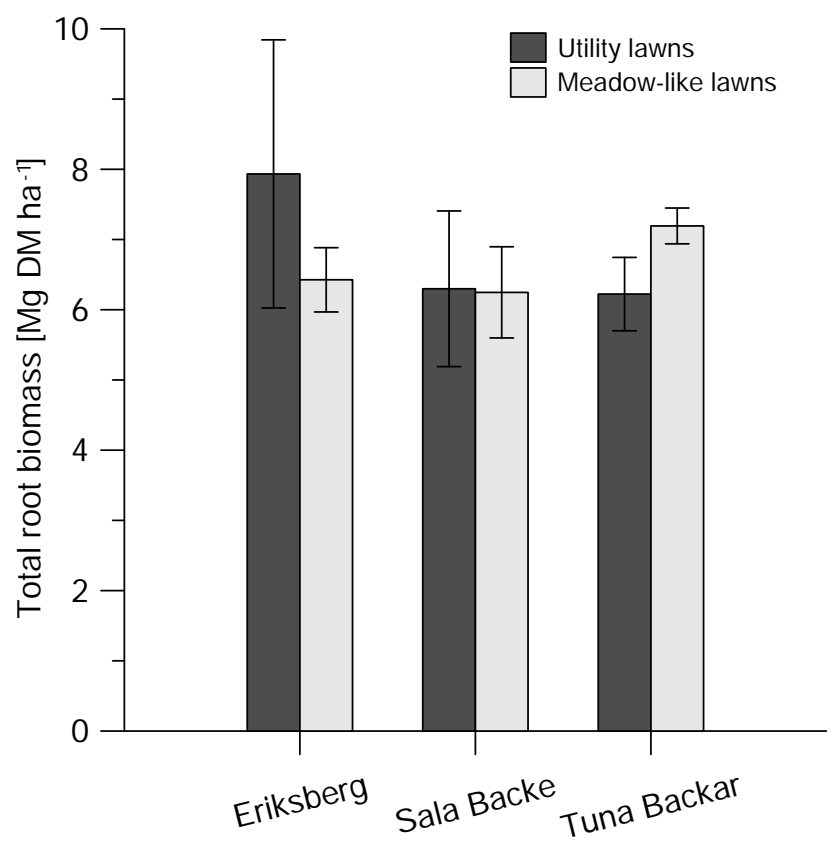

Figure 3. Bar plot showing total root biomass at $0-10 \mathrm{~cm}$ depth for the two different lawn types at the study sites in Uppsala. Error bars indicate standard deviation.

Gothenburg, we found one site with higher average SOC concentration in the meadow-like lawns. The calculated SOC stocks are listed in Table 2. The average SOC stock difference between the two differently managed lawn types was $7.8 \mathrm{Mg} \mathrm{ha}^{-1}$ or $12 \%$. The very similar patterns observed for the variables NPP and SOC suggest that the SOC changes were driven by NPP and thus carbon input. In fact, the difference in SOC stock between management regimes at each site was significantly correlated to the difference in NPP (Fig. 5). No other parameter added significant explanation to the model fit. Although clay content did not improve the model fit of the generalized linear model, difference in SOC stock also increased with average clay content $\left(R^{2}=0.26\right.$, $p=0.1$, not shown). This correlation is, however, strongly driven by the sites in Uppsala, which showed the highest increase in both NPP and SOC. Thus, local management differences, which are, however, not available in detail, might also have influenced the observed treatment effect on SOC to some degree.

The soil $\mathrm{C}: \mathrm{N}$ ratio of the meadow-like lawns $(13.2 \pm 1.2)$ was significantly higher $(p=0.007)$ than that of the utility lawns $(12.6 \pm 0.7)$, indicating that the soil organic matter under the utility lawns was relatively enriched in nitrogen (Fig. 6). 
Table 2. Soil bulk density (BD) $\left[\mathrm{g} \mathrm{cm}^{-3}\right]$ and SOC stocks $\left[\mathrm{Mg} \mathrm{ha}^{-1}\right]$ according to Eq. (3). Standard deviation is given in brackets.

\begin{tabular}{llllllcccc}
\hline City & Site & \multicolumn{2}{c}{ Utility lawn } & \multicolumn{2}{c}{ Meadow-like lawn } & \multicolumn{2}{c}{ Utility lawn } & \multicolumn{2}{c}{ Meadow-like lawn } \\
\hline & & BD & & BD & & \multicolumn{2}{c}{ SOC stock } & \multicolumn{2}{c}{ SOC stock } \\
\hline \multirow{2}{*}{ Uppsala } & Eriksberg & 1.13 & $(0.04)$ & 1.13 & $(0.16)$ & 74.8 & $(11.4)$ & 63.1 & $(8.7)$ \\
& Sala Backe & 1.14 & $(0.03)$ & 1.1 & $(0.07)$ & 96.2 & $(9.3)$ & 69.8 & $(24.2)$ \\
& Tuna Backar & 1.15 & $(0.07)$ & 1.21 & $(0.06)$ & 72.4 & $(13.3)$ & 47.6 & $(19.5)$ \\
\hline \multirow{2}{*}{ Malmö } & Kirseberg & 1.03 & $(0.07)$ & 1.02 & $(0.08)$ & 69.4 & $(4.5)$ & 52.7 & $(0.95)$ \\
& Sibbarp & 1.04 & $(0.06)$ & 0.98 & $(0.06)$ & 75 & $(8.3)$ & 96.4 & $(3.5)$ \\
& Augustenborg & 1.03 & $(0.06)$ & 1.18 & $(0.15)$ & 59.1 & $(9.4)$ & 50.3 & $(22.4)$ \\
\hline \multirow{2}{*}{ Gothenburg } & Guldhelden & 0.87 & $(0.14)$ & 0.88 & $(0.21)$ & 86.2 & $(2.3)$ & 78.4 & $(21.3)$ \\
& Kyrkbyn & 0.99 & $(0.09)$ & 0.88 & $(0.06)$ & 68.2 & $(8.1)$ & 77.9 & $(7.8)$ \\
& Björkekärr & 0.96 & $(0.1)$ & 0.99 & $(0.08)$ & 67 & $(14.4)$ & 61.2 & $(3.1)$ \\
\hline
\end{tabular}

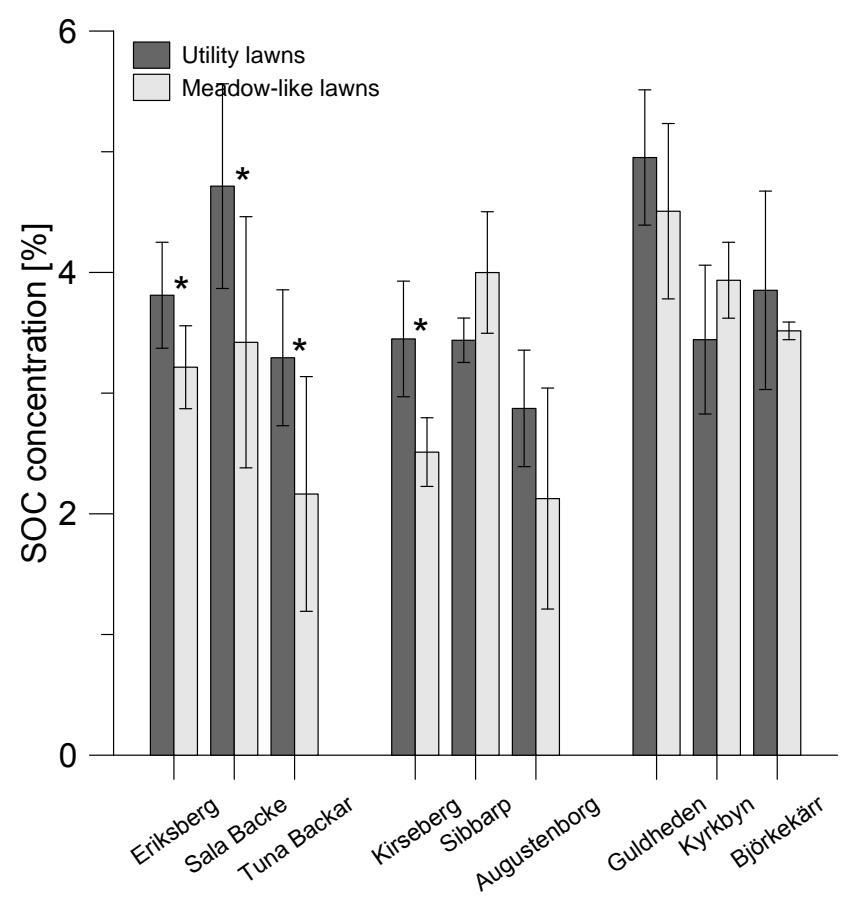

Figure 4. Bar plot showing measured soil organic carbon (SOC) concentration in the two different lawn types at each site. Error bars indicate standard deviation and stars indicate significant difference between treatments at the specific site $(p<0.05)$.

\section{Discussion}

\subsection{Effect of cutting frequency on aboveground productivity}

We showed that cutting frequency significantly altered the aboveground biomass production in urban lawns. This can be explained by the fact that canopy $\mathrm{CO}_{2}$ assimilation is a function of the amount of assimilating plant matter (Wohlfahrt et al., 2008). Wohlfahrt et al. (2008) showed that when the green area index (GAI) of an alpine grassland exceeded

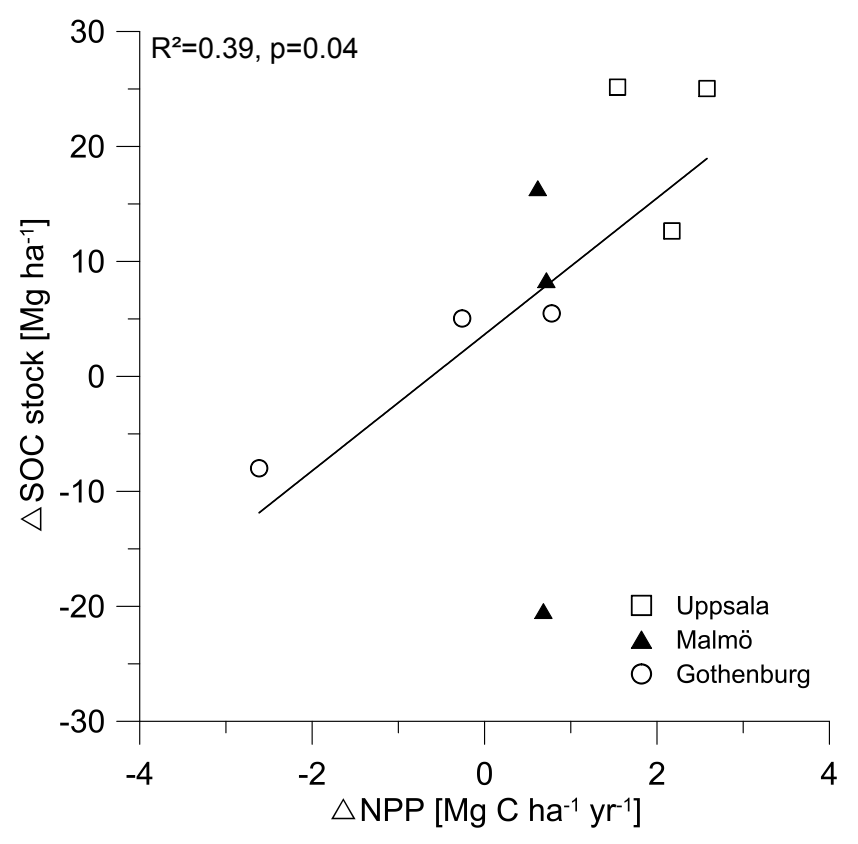

Figure 5. Difference in soil organic carbon (SOC) stock between utility and meadow-like lawns as a function of difference in aboveground NPP for all sites.

$4 \mathrm{~m}^{2} \mathrm{~m}^{-2}$, the gross primary production (GPP) decreased due to shading, but also due to plant phenology. Directly after cutting (three cuts per season), their grassland had a GAI of $0.5-2 \mathrm{~m}^{2} \mathrm{~m}^{-2}$, while directly before cutting it had a GAI $>6 \mathrm{~m}^{2} \mathrm{~m}^{-2}$. The meadow-like lawns in our study were only cut once, which indicates that the period in which the GAI of the canopy exceeded the optimum for $\mathrm{CO}_{2}$ assimilation was very long. In contrast, the GAI of the utility lawn remained relatively close to the optimum throughout the entire growing period. Furthermore, Klimeš and Klimešová (2002) found that frequent mowing promoted the dominance of efficiently regrowing plant species, which might provide an additional explanation for the higher NPP in our util- 


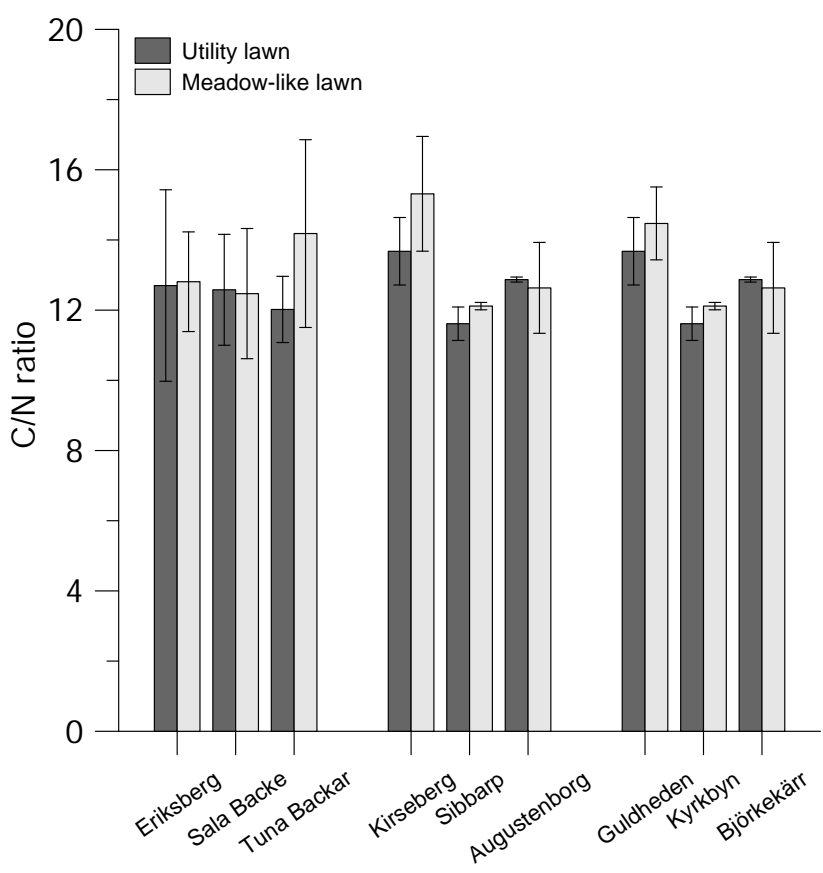

Figure 6. Bar plot showing measured $\mathrm{C}: \mathrm{N}$ ratio of the two different lawn types at each site. Error bars indicate standard deviation.

ity lawns. Our results are also in agreement with Kaye et al. (2005), who found 5-fold higher aboveground NPP in an urban lawn than in a short-grass steppe. However, the urban lawn in that study was fertilised and irrigated, while the urban lawns in our study were not. In a long-term field experiment on cutting frequency effects on grass yield, Kramberger et al. (2015) found the lowest yield in plots with the highest cutting frequency (2-week intervals) and the highest yield in plots with moderate to low cutting frequency (8- to 12-week intervals). This is in contrast to our results from Uppsala and Malmö, but in line with the results from Gothenburg, where we found higher aboveground biomass in the meadow-like lawns. However, we are unable to explain the much higher NPP of the meadow-like lawns in Kyrkbyn.

\subsection{Effect of cutting frequency on soil organic carbon in relation to similar management contrasts}

The higher aboveground NPP in the utility lawns had a significant positive effect on soil carbon. This was expected, since the clippings were not removed and were thus able to contribute directly to soil organic matter formation. For this reason, the results of our study are not directly applicable to mown grasslands or leys, which are usually harvested. The responses of SOC to management intensity in those systems are not well studied, but studies performed to date show mixed results ranging from no effect (Kramberger et al., 2015) to significantly positive effects of high cutting frequency (Ammann et al., 2007). In the latter case, the difference in SOC stocks between intensively and extensively managed grassland was attributed to differences in $\mathrm{N}$ fertilisation, which caused $\mathrm{N}$ deficiency and thus $\mathrm{N}$ mining in the extensive grassland, leading to stronger mineralisation of stable organic matter. The effects of grazing intensity on SOC are much better studied than the effects of mowing intensity. Both positive (Reeder et al., 2004; Smoliak et al., 1972) and negative (Abril and Bucher, 2001; Su et al., 2005) effects of low compared with high grazing intensity on SOC have been reported. However, many of the studies reporting negative effects of intensive grazing refer to overgrazing in semiarid areas, which is associated with strongly reduced vegetation cover and soil erosion. The actual effects seem to be contextspecific, as found in a global meta-analysis conducted by McSherry and Ritchie (2013). The found positive correlation of difference in SOC and average clay content across sites has to be interpreted with caveats, since a clear causality is not given. It is realistic that more of the $\mathrm{C}$ input is stabilised in clay-rich soils (Poeplau et al., 2015b). However, this correlation did not hold within the three sites at each city, which indicates that the correlation found of clay and difference in SOC, as well as of clay and difference in NPP, across all sites might also resemble a random city effect.

Overall, our findings and those of previous studies (Christopher and Lal, 2007; Poeplau et al., 2015a) confirm that plant input driven by NPP is the major driver for SOC dynamics. Root carbon input is recognised as being of major importance for building up soil organic matter, since a higher fraction of root-derived carbon is stabilised in the soil than in aboveground plant material (Kätterer et al., 2011). In temperate grasslands, up to $70 \%$ of the total NPP is allocated to roots and their exudates (Bolinder et al., 2007). However, in the present study, management intensity did not significantly influence root biomass, indicating that root production was relatively favoured in the meadow-like lawns. A similar finding has been reported in a study which found higher root biomass under diverse swards than under conventional, intensively managed ryegrass-clover pastures (McNally et al., 2015). Altered root production could therefore not explain observed differences in SOC stocks in our study. However, the informative value of the obtained root data is certainly limited, since root biomass was only determined in one city, to a depth of $10 \mathrm{~cm}$ and at one point in time. It can thus not be assumed that the measured root biomass measured is representative of root growth throughout the season (Ziter and MacDougall, 2013). Furthermore, potential management effects on the depth distribution of belowground biomass cannot be inferred.

The proportion of aboveground plant material stabilised in the soil has been estimated to be $13 \%$ in a Swedish long-term agricultural field experiment (Andrén and Kätterer, 1997). Similar values, i.e. around $10 \%$, have been reported in other studies (Lehtinen et al., 2014; Poeplau et al., 2015b). It can be assumed that lawn clippings undergo slightly lower stabilisation than straw in agricultural systems, due to the lack of mixing of residues with stabilising mineral soil parti- 
cles (Wiesmeier et al., 2014). The mean annual difference in SOC sequestration between the two lawn types we studied was $120 \mathrm{~kg} \mathrm{Cha}^{-1} \mathrm{yr}^{-1}$. Assuming a constant stabilisation rate of $10 \%$ across all sites, the calculated difference in SOC sequestration due only to different amounts of recycled clippings would have been $69 \mathrm{~kg} \mathrm{Cha}^{-1} \mathrm{yr}^{-1}$, which is only slightly more than half the observed difference. Several studies report accelerated root turnover in more intensively managed grassland (Klumpp et al., 2009; Leifeld et al., 2015). However, accelerated root turnover could result in either more or less root-derived SOC, depending on the effect on total root growth and exudations throughout the year, which is difficult to investigate (Johnen and Sauerbeck, 1977).

Interestingly, the soil $\mathrm{C}: \mathrm{N}$ ratio was significantly lower in the utility lawns than in the meadow-like lawns, although neither system was fertilised and both were equally exposed to $\mathrm{N}$ deposition. Furthermore, the proportion of $\mathrm{N}$-fixing leguminous plants was higher in the utility lawns than in the meadow-like lawns only in Gothenburg. This might indicate that nitrogen cycling was more closed in the utility lawns. Potentially, more nitrogen is lost via leaching in the meadowlike lawns, because $\mathrm{N}$ mineralisation and plant $\mathrm{N}$ demand occur asynchronously (Dahlin et al., 2005). The peak in N mineralisation usually occurs around midsummer (Paz-Ferreiro et al., 2012), which might be too late for plant uptake when the grass is not mown and would lead to $\mathrm{N}$ losses from the system. Another pathway of $\mathrm{N}$ loss is ammonia $\left(\mathrm{NH}_{3}\right)$ volatilisation, which increases in later development stages of the plant due to ontogenetic changes in plant $\mathrm{N}$ metabolism (Morgan and Parton, 1989). Whitehead and Lockyer (1989) showed $10 \% \mathrm{~N}$ losses from decomposing grass herbage by $\mathrm{NH}_{3}$ volatilisation. The consequences of $\mathrm{N}$ deficiency for SOC dynamics are twofold: (i) decreased NPP and thus decreased carbon input (Christopher and Lal, 2007) and (ii) increased heterotrophic respiration due to $\mathrm{N}$ mining in more recalcitrant organic matter (Ammann et al., 2007). In an incubation experiment, Kirkby et al. (2014) showed that more aboveground residues were stabilised in the soil when nitrogen was added. Thus, negative effects of lawn management on soil N storage can feed back onto SOC, which might also explain a certain proportion of the observed differences in SOC.

\subsection{Implications for urban soil management}

During the past decade, several studies have investigated biogeochemical cycles in urban soils, since their relevance for the global carbon cycle and as a fundamental ecological asset in an urbanising world is becoming increasingly evident (Lehmann and Stahr, 2007; Lorenz and Lal, 2009). Compared with data on agricultural land with similarly textured soils in the surroundings of the study sites extracted from a national soil inventory database, we found on average $55 \%$ (utility lawns) and 35\% (meadow-like lawns) higher SOC stocks in the lawns we investigated. Furthermore, it has been found in several studies that urban soils have higher carbon stocks than native soils in adjacent rural areas, which can be attributed in particular to more optimised, but also resourceconsuming, management, including fertilisation and irrigation (Edmondson et al., 2012; Kaye et al., 2005; Pouyat et al., 2009). However, in the present study we were able to show that SOC storage in urban lawns can be increased at comparatively low cost under temperate climate conditions by optimising NPP and leaving residues on the lawn. Losses of carbon and nutrients are thereby minimised. Milesi et al. (2005) used the BIOME-BGC model to compare different lawn management scenarios and found that applying $73 \mathrm{~kg} \mathrm{~N}$ and recycling the clippings was more efficient for SOC sequestration $(+40 \%)$ than applying $146 \mathrm{~kg} \mathrm{~N}$ and removing the clippings. For the sites in Uppsala, Wesström (2015) calculated that the management of utility lawns creates $54 \mathrm{~kg} \mathrm{ha}^{-1} \mathrm{yr}^{-1}$ more $\mathrm{C}$ emissions than the management of meadow-like lawns. With this value subtracted from the annual difference in SOC sequestration that we found $\left(120 \mathrm{~kg} \mathrm{Cha}^{-1} \mathrm{yr}^{-1}\right)$, the utility lawns in our study sequester a non-significant amount of $66 \mathrm{~kg} \mathrm{ha}^{-1} \mathrm{yr}^{-1}$ more carbon than the meadow-like lawns. However, for a full greenhouse gas budget, the effects of lawn management on other trace gases, primarily nitrous oxide $\left(\mathrm{N}_{2} \mathrm{O}\right)$, have to be considered (Townsend-Small and Czimczik, 2010). In that case, management of the clippings will most likely play a key role, since coverage of the soil with organic material increases soil moisture and the availability of labile carbon but decreases soil oxygen, all of which favour $\mathrm{N}_{2} \mathrm{O}$ formation (Larsson et al., 1998; Petersen et al., 2011).

\section{Conclusions}

This investigation of urban lawns in three Swedish cities showed that cutting frequency alone can exert a significant influence on soil carbon, mainly by increasing net primary production and thus carbon inputs. However, this is most likely only true when cuttings are left on the lawn, since belowground production did not show any differential response to cutting frequency. Moreover, the observed difference in soil carbon could not be fully explained by the expected stabilisation of aboveground-derived carbon input differences, which might denote that either root-derived carbon dynamics or nitrogen mining also play an important role. If clippings are left on the lawn, nitrous oxide emissions might comprise a significant fraction of the greenhouse gas budget of lawns and have to be accounted for to judge the climate mitigation potential of contrasting lawn or grassland management strategies.

Acknowledgements. This study was funded by Formas, the Swedish Research Council for Environment, Agricultural Sciences and Spatial Planning (contract 225-2012-1369). 
Edited by: C. Boix-Fayos

\section{References}

Abril, A. and Bucher, E. H.: Overgrazing and soil carbon dynamics in the western Chaco of Argentina, Appl. Soil Ecol., 16, 243249, 2001

Ammann, C., Flechard, C. R., Leifeld, J., Neftel, A., and Fuhrer, J.: The carbon budget of newly established temperate grassland depends on management intensity, Agr. Ecosyst. Environ., 121, 5-20, 2007.

Andrén, O. and Kätterer, T.: ICBM: the introductory carbon balance model for exploration of soil carbon balances, Ecol. Appl., 7, 1226-1236, 1997.

Bolinder, M., Janzen, H., Gregorich, E., Angers, D., and VandenBygaart, A.: An approach for estimating net primary productivity and annual carbon inputs to soil for common agricultural crops in Canada, Agr. Ecosyst. Environ., 118, 29-42, 2007.

Bolinder, M. A., Kätterer, T., Andrén, O., and Parent, L. E.: Estimating carbon inputs to soil in forage-based crop rotations and modeling the effects on soil carbon dynamics in a Swedish longterm field experiment, Can. J. Soil Sci., 92, 821-833, 2012.

Chapin, S. I., McFarland, J., McGuire, A. D., Euskirchen, E. S., Ruess, R. W., and Kielland, K.: The changing global carbon cycle: linking plant-soil carbon dynamics to global consequences, J. Ecol., 97, 840-850, 2009.

Christopher, S. F. and Lal, R.: Nitrogen Management Affects Carbon Sequestration in North American Cropland Soils, Crit. Rev. Plant Sci., 26, 45-64, 2007.

Dahlin, S., Kirchmann, H., Kätterer, T., Gunnarsson, S., and Bergström, L.: Possibilities for Improving Nitrogen Use From Organic Materials in Agricultural Cropping Systems, AMBIO, 34, 288-295, 2005.

Debreczeni, K. and Körschens, M.: Long-term field experiments of the world, Arch. Acker Pfl. Boden., 49, 465-483, 2003.

Edmondson, J. L., Davies, Z. G., McHugh, N., Gaston, K. J., and Leake, J. R.: Organic carbon hidden in urban ecosystems, Scientific Reports, 2, 963, 2012.

Edmondson, J. L., Davies, Z. G., McCormack, S. A., Gaston, K. J., and Leake, J. R.: Land-cover effects on soil organic carbon stocks in a European city, Sci. Total Environ., 472, 444-453, 2014.

Ellert, B. H. and Bettany, J. R.: Calculation of organic matter and nutrients stored in soils under contrasting management regimes, Can. J. Soil Sci., 75, 529-538, 1995.

Ignatieva, M., Ahrné, K., Wissman, J., Eriksson, T., Tidåker, P., Hedblom, M., Kätterer, T., Marstorp, H., Berg, P., and Eriksson, T.: Lawn as a cultural and ecological phenomenon: A conceptual framework for transdisciplinary research, Urban For. Urban Gree., 14, 383-387, 2015.

Janzen, H. H., Entz, T., and Ellert, B. H.: Correcting mathematically for soil adhering to root samples, Soil Biol. Biochem., 34, 19651968, 2002.

Johnen, B. and Sauerbeck, D.: A tracer technique for measuring growth, mass and microbial breakdown of plant roots during vegetation, Ecol. Bull., 1977, 366-373, 1977.

Kätterer, T., Bolinder, M. A., Andrén, O., Kirchmann, H., and Menichetti, L.: Roots contribute more to refractory soil organic matter than above-ground crop residues, as revealed by a longterm field experiment, Agr. Ecosyst. Environ., 141, 184-192, 2011.

Kaye, J., McCulley, R. L., and Burke, I.: Carbon fluxes, nitrogen cycling, and soil microbial communities in adjacent urban, native and agricultural ecosystems, Glob. Change Biol., 11, 575-587, 2005.

Kirkby, C. A., Richardson, A. E., Wade, L. J., Passioura, J. B., Batten, G. D., Blanchard, C., and Kirkegaard, J. A.: Nutrient availability limits carbon sequestration in arable soils, Soil Biol. Biochem., 68, 402-409, 2014.

Klimeš, L. and Klimešová, J.: The effects of mowing and fertilization on carbohydrate reserves and regrowth of grasses: do they promote plant coexistence in species-rich meadows?, in: Ecology and Evolutionary Biology of Clonal Plants, edited by: Stuefer, J. F., Erschbamer, B., Huber, H., and Suzuki, J. I., Springer Netherlands, 2002.

Klumpp, K., Fontaine, S., Attard, E., Le Roux, X., Gleixner, G., and Soussana, J. F.: Grazing triggers soil carbon loss by altering plant roots and their control on soil microbial community, J. Ecol., 97, 876-885, 2009.

Kowalchuk, G. A., Buma, D. S., de Boer, W., Klinkhamer, P. G., and van Veen, J. A.: Effects of above-ground plant species composition and diversity on the diversity of soil-borne microorganisms, Antonie van Leeuwenhoek, 81, 509-520, 2002.

Kramberger, B., Podvršnik, M., Gselman, A., Šuštar, V., Kristl, J., Muršec, M., Lešnik, M., and Škorjanc, D.: The effects of cutting frequencies at equal fertiliser rates on bio-diverse permanent grassland: Soil organic C and apparent N budget, Agr. Ecosyst. Environ., 212, 13-20, 2015.

Larsson, L., Ferm, M., Kasimir-Klemedtsson, A., and Klemedtsson, L.: Ammonia and nitrous oxide emissions from grass and alfalfa mulches, Nutr. Cycl. Agroecosys., 51, 41-46, 1998.

Lehmann, A. and Stahr, K.: Nature and significance of anthropogenic urban soils, J. Soil. Sediment., 7, 247-260, 2007.

Lehtinen, T., Schlatter, N., Baumgarten, A., Bechini, L., Krüger, J., Grignani, C., Zavattaro, L., Costamagna, C., and Spiegel, H.: Effect of crop residue incorporation on soil organic carbon and greenhouse gas emissions in European agricultural soils, Soil Use Manage., 30, 524-538, 2014.

Leifeld, J., Meyer, S., Budge, K., Sebastia, M. T., Zimmermann, M., and Fuhrer, J.: Turnover of Grassland Roots in Mountain Ecosystems Revealed by Their Radiocarbon Signature: Role of Temperature and Management, PloS one, 10, e0119184, doi:10.1371/journal.pone.0119184, 2015.

Lorenz, K. and Lal, R.: Biogeochemical C and N cycles in urban soils, Environ. Int., 35, 1-8, 2009.

McNally, S., Laughlin, D., Rutledge, S., Dodd, M., Six, J., and Schipper, L.: Root carbon inputs under moderately diverse sward and conventional ryegrass-clover pasture: implications for soil carbon sequestration, Plant Soil, 392, 289-299, 2015.

McSherry, M. E. and Ritchie, M. E.: Effects of grazing on grassland soil carbon: a global review, Glob. Change Biol., 19, 1347-1357, 2013.

Milesi, C., Elvidge, C., Dietz, J., Tuttle, B., Nemani, R., and Running, S.: A strategy for mapping and modeling the ecological effects of US lawns, J. Turfgrass Manage., 1, 83-97, 2005.

Morgan, J. A. and Parton, W. J.: Characteristics of Ammonia Volatilization from Spring Wheat, Crop Sci., 29, 726-731, 1989. 
Paz-Ferreiro, J., Baez-Bernal, D., Castro-Insúa, J., and GarcíaPomar, M. I.: Temporal Variability of Soil Biological Properties in Temperate Grasslands and Croplands Amended with Organic and Inorganic Fertilizers, Commun. Soil Sci. Plant Anal., 44, 1927, 2012.

Petersen, S. O., Mutegi, J. K., Hansen, E. M., and Munkholm, L. J.: Tillage effects on $\mathrm{N}_{2} \mathrm{O}$ emissions as influenced by a winter cover crop, Soil Biol. Biochem., 43, 1509-1517, 2011.

Pinheiro, J., Bates, D., DeBroy, S., and Sarkar, D.: nlme: Linear and Nonlinear Mixed Effects, Models, R package version 3, 196, 2009.

Poeplau, C. and Don, A.: Sensitivity of soil organic carbon stocks and fractions to different land-use changes across Europe, Geoderma, 192, 189-201, 2013.

Poeplau, C., Aronsson, H., Myrbeck, Å., and Kätterer, T.: Effect of perennial ryegrass cover crop on soil organic carbon stocks in southern Sweden, Geoderma Regional, 4, 126-133, $2015 \mathrm{a}$.

Poeplau, C., Kätterer, T., Bolinder, M. A., Börjesson, G., Berti, A., and Lugato, E.: Low stabilization of aboveground crop residue carbon in sandy soils of Swedish long-term experiments, Geoderma, 237-238, 246-255, 2015b.

Pouyat, R., Yesilonis, I., and Golubiewski, N.: A comparison of soil organic carbon stocks between residential turf grass and native soil, Urban Ecosyst., 12, 45-62, 2009.

Qian, Y., Follett, R. F., and Kimble, J. M.: Soil organic carbon input from urban turfgrasses, Soil Sci. Soc. Am. J., 74, 366-371, 2010.

Raciti, S. M., Groffman, P. M., Jenkins, J. C., Pouyat, R. V., Fahey, T. J., Pickett, S. T., and Cadenasso, M. L.: Accumulation of carbon and nitrogen in residential soils with different land-use histories, Ecosystems, 14, 287-297, 2011.

Reeder, J. D., Schuman, G. E., Morgan, J. A., and LeCain, D. R.: Response of Organic and Inorganic Carbon and Nitrogen to Long-Term Grazing of the Shortgrass Steppe, Environ. Manage., 33, 485-495, 2004.

Seiger, L. and Merchant, H.: Mechanical control of Japanese knotweed (Fallopia japonica [Houtt.] Ronse Decraene): Effects of cutting regime on rhizomatous reserves, Nat. Area. J., 17, 341345, 1997.

Smoliak, S., Dormaar, J. F., and Johnston, A.: Long-Term Grazing Effects on Stipa-Bouteloua Prairie Soils, J. Range Manage., 25, 246-250, 1972.
Soussana, J., Allard, V., Pilegaard, K., Ambus, P., Amman, C., Campbell, C., Ceschia, E., Clifton-Brown, J., Czóbel, S., and Domingues, R.: Full accounting of the greenhouse gas $\left(\mathrm{CO}_{2}\right.$, $\mathrm{N}_{2} \mathrm{O}, \mathrm{CH}_{4}$ ) budget of nine European grassland sites, Agr. Ecosyst. Environ., 121, 121-134, 2007.

Su, Y.-Z., Li, Y.-L., Cui, J.-Y., and Zhao, W.-Z.: Influences of continuous grazing and livestock exclusion on soil properties in a degraded sandy grassland, Inner Mongolia, northern China, CATENA, 59, 267-278, 2005.

Townsend-Small, A. and Czimczik, C. I.: Carbon sequestration and greenhouse gas emissions in urban turf, Geophys. Res. Lett., 37, doi:10.1029/2009GL041675, 2010.

Wesström, T.: Energy use and carbon footprint from lawn management, Masters, Swedish University of Agricultural Sciences, Uppsala, 2015.

Whitehead, D. and Lockyer, D.: Decomposing grass herbage as a source of ammonia in the atmosphere, Atmos. Environ., 23, 1867-1869, 1989.

Wiesmeier, M., Schad, P., von Lützow, M., Poeplau, C., Spörlein, P., Geuß, U., Hangen, E., Reischl, A., Schilling, B., and Kögel-Knabner, I.: Quantification of functional soil organic carbon pools for major soil units and land uses in southeast Germany (Bavaria), Agr. Ecosyst. Environ., 185, 208-220, 2014.

Wohlfahrt, G., Hammerle, A., Haslwanter, A., Bahn, M., Tappeiner, U., and Cernusca, A.: Seasonal and inter-annual variability of the net ecosystem $\mathrm{CO}_{2}$ exchange of a temperate mountain grassland: Effects of weather and management, J. Geophys. Res.-Atmos., 113, doi:10.1029/2007JD009286, 2008.

Yan, W. and Hunt, L. A.: An Equation for Modelling the Temperature Response of Plants using only the Cardinal Temperatures, Ann. Bot.-London, 84, 607-614, 1999.

Zeeman, M. J., Hiller, R., Gilgen, A. K., Michna, P., Plüss, P., Buchmann, N., and Eugster, W.: Management and climate impacts on net $\mathrm{CO}_{2}$ fluxes and carbon budgets of three grasslands along an elevational gradient in Switzerland, Agr. Forest Meteorol., 150, 519-530, 2010.

Ziter, C. and MacDougall, A. S.: Nutrients and defoliation increase soil carbon inputs in grassland, Ecology, 94, 106-116, 2013. 